\title{
ECOLOGICAL ANALYSIS OF GELAM (Melaleuca cajuputi) ON PEATLAND IN SOUTH KALIMANTAN
}

\author{
Yudi Firmanul Arifin ${ }^{1,2, *)}$, Siti Hamidah ${ }^{1,2)}$, and Yulian Firmana Arifin ${ }^{3)}$ \\ 1) Faculty of Forestry Unlam \\ 2) Consortium for Sustainable Tropical Forest Management \\ 3) Faculty of Engineering \\ ${ }^{*}$ Correspounding author: yudifirmanul@yahoo.com; konsorsium.phtb@gmail.com
}

\begin{abstract}
Until now the raw material of wood especially Gelam (Melaleuca cajuputi) for supporting the construction of housing and other infrastructures is increasingly demand in Indonesia. On the Island of Borneo that partly consists of peat swamps needs Gelam very large and continuous, particularly for residential development. Ecological aspects are very important for supporting the silvicultural strategies. The aim of this study is to analyze ecological aspects which are very influence especially physical and chemical soil properties and microclimate as well. The utilization of study is to determine the silvicultural strategies for continuing production and conservation of Gelam in the future. The method was used a field survey around Gelam forest and did collecting samples and measuring there. The results showed in South Borneo the potency of Gelam is only $2,9-7,1 \mathrm{~m}^{3} / \mathrm{ha}$ and decreasing yearly. Normally Gelam with a diameter $<4 \mathrm{~cm}$ have been cut down, as well as $>30 \mathrm{~cm}$. Gelam can grow on the peat swamp forest where the soil was low pH 3.5-3.9. Most of $\mathrm{pH}$ of soil in these areas was influenced by phyrite $\left(\mathrm{FeS}_{2}\right.$ of $0.4-2.2 \%$ and highest of $\mathrm{Fe} 90-302 \mathrm{ppm}$. C organic in the soil was included low-moderate 5.5-10.0\%. Result of soil physic analysis showed composition of sand, dust, and clay of $9: 54: 57 \%$ respectively. Temperature and humidity around peat swamp forest areas where was found Gelam were 31$33^{\circ} \mathrm{C}$ and $63-73 \%$ respectively. Most of areas around Gelam were grown Gelam Tikus (Syzygium inophylla) and some kind of shrubs.
\end{abstract}

Key words: Gelam, potency, ecological aspects, silviculture

\section{INTRODUCTION}

Research on Gelam plant is not yet widely done, the data obtained more than writing some text book, not the result of research published in the journal, so that reference about this plant is still very little. But in terms of the importance of this plant for development, especially the development of infrastructure such as; houses, bridges, and other research on softwood will support the conservation and optimal utilization.

Gelam (Melaleuca cajuputi) are found in peat swamp forests are affected by the tidal ebb and flow. This type of fire climax classified as pioneer species, which after forest fires will only increase seed germination, because fire can clean up litter and dormant seeds of other plant species which become competitors (Mac Kinnnon et al. 1985).

Gelam spreads in Southeast Asia from the Malay Peninsula to the Maluku Islands. In Indonesia, naturally this species is found in South Sumatra, Central Sulawesi, Bali, Coastal South Kalimantan, Central Kalimantan and Irian Jaya (Samingan 1971). In South Kalimantan it is also found in relatively dry land (the former heath forest) such as; The Sebuhur, Liang Anggang, Village Ulin Platform, and Liang area Anggang District of Bat-bati.Gelam forests are forests that are in the area of peat swamp forest with a fairly high soil acidity. Gelam forest is generally homogeneous forest, but there is also growing in freshwater.
Before Gelam cultivation is needed to analyze is suitable habitat to growing up the success of plantations. This research is designed to give a description of gelam habitat in South Kalimantan.

\section{METHODS}

Inventory to determine the potential and ecological conditions.

1) Observation of Gelam conducted in Batola District, Banjar District, Tanah Laut District, and Tapin District, South Kalimantan.

2) Observation began with the recognition of the existence of Gelam in the study site, which is monitored through reports and information from the local community.

3) If the information obtained indicates that the source of Gelam, then survey was done using plots of $200 \mathrm{x}$ $200 \mathrm{~m}$ is divided into sub-sub plots with a size of 20 $\mathrm{x} 20 \mathrm{~m}$.

\section{RESULT AND DISCUSSION}

\section{The potency of Gelam}

The use of Gelam is increasing not only for the development of construction of houses on stilts in swamp areas, but it is also used for the manufacture of 
boards or beams to the interior of the house, and pieces or wastes used as firewood. Most people use for firewood which is marketed in Batola and Bati-Bati. Gelam sourced from seeds generally have a relatively straight of stem and have monopodial branching shape, so that the stems are widely used for materials / wood construction. Contrary, the tree which is derived by coppices tends sympodial branching shape, so it is often used for firewood. If the stem diameter $>20 \mathrm{~cm}$ and length $>4 \mathrm{~m}$ used as carpentry (Lazuardi and Supriadi 2000).

In the district of Batola as center of Gelam producers in South Kalimantan has the potential volume around to 2.9 to $7.1 \mathrm{~m}^{3}$ / ha. This district is bordered by Kapuas so the majority of raw materials for South Kalimantan region supported by Kapuas District.

\section{The Habitat}

\section{Micro climate}

Based on the measurement of microclimate data in the research sites, it seems that the three study sites have similar micro-climatic conditions. Average temperatures ranged from 31.2 to $32.6^{\circ} \mathrm{C}$, and humidity $63-73 \%$. This situation shows that Gelam grows in open areas and do not require shade.

Table 1. Micro climate around Gelam Forest

\begin{tabular}{lccc}
\hline & \multicolumn{3}{c}{ Result of Measurement } \\
\cline { 2 - 4 } Parameter & $\begin{array}{l}\text { Gelam } \\
\text { Forest in } \\
\text { Antarjaya } \\
\text { Village }\end{array}$ & $\begin{array}{l}\text { Gelam } \\
\text { Forest in } \\
\text { Antarbaru } \\
\text { Village }\end{array}$ & $\begin{array}{l}\text { Gelam } \\
\text { Forest in } \\
\text { Teluk } \\
\text { Tamba } \\
\text { Village }\end{array}$ \\
\hline $\begin{array}{l}\text { Temperature } \\
\left({ }^{\circ} \mathrm{C}\right)\end{array}$ & 31.5 & 31.2 & 32.6 \\
Humidity $(\%)$ & 68.0 & 73.0 & 63.0 \\
\hline
\end{tabular}

\section{Physical and Chemical Soil}

Gelam (Melaleuca cajuputi) was found on the peat swamp forests which is influenced by tides. This species is classified as pioneer species, which after a forest fire seed germination will increase, because the fire can clean up litter and dormant seeds (Mac Kinnnon et al. 1985).

Table 2. Texture of soil on the Gelam Forest

\begin{tabular}{llllll}
\hline \multirow{2}{*}{ No. } & Parameter & \multicolumn{4}{c}{ Location } \\
\cline { 3 - 6 } & & Plot 1 & Plot2 & Plot3 & Plot4 \\
\hline 1 & Sand (\%) & 5.01 & 12.00 & 11.44 & 5.93 \\
2 & Dust (\%) & 32.65 & 32.91 & 36.22 & 50.46 \\
3 & Clay (\%) & 62.34 & 55.09 & 52.34 & 43.61 \\
\hline
\end{tabular}

Soil texture shows a comparison of the proportion of sand (diameter 2.00 to $0.05 \mathrm{~mm}$ ), dust $(0.005$ to 0.02 $\mathrm{mm})$ and clay $(<0.002 \mathrm{~mm})$ in the soil. The soil in the study site consist of clayey class (Table 2), with the consistency of the soil is generally very closely to wet soil category. These results indicate that clay content is higher than that of dust and sand.
Table 3. Chemical Compounds in the soil

\begin{tabular}{|c|c|c|c|c|c|}
\hline \multirow{3}{*}{ No } & \multirow{3}{*}{ Parameter } & \multicolumn{4}{|c|}{ Location } \\
\hline & & Plot 1 & Plot 2 & Plot 3 & Plot 4 \\
\hline & & Batola & Batola & Batola & Tapin \\
\hline 1 & $\mathrm{pH}$ & 3.46 & 3.58 & 3.69 & 3.86 \\
\hline 2 & Ntot & 1.23 & 0.90 & 1.21 & 1.29 \\
\hline 3 & $\begin{array}{l}\text { C-organic } \\
(\%)\end{array}$ & 6.55 & 8.14 & 5.51 & 10.02 \\
\hline 4 & $\begin{array}{l}\mathrm{P}_{2} \mathrm{O}_{5} \mathrm{mg} / \\
100 \text { gram }\end{array}$ & 83.38 & 100.46 & 175.11 & 79.49 \\
\hline 5 & $\begin{array}{l}\mathrm{K}_{2} \mathrm{O} \mathrm{mg/} \\
100 \text { gram }\end{array}$ & 10.74 & 10.78 & 21.55 & 22.35 \\
\hline 6 & Fe ppm & 302.89 & 132.23 & 197.52 & 90.00 \\
\hline 7. & Pyrite (\%) & 0.42 & 2.20 & 0.45 & 0.58 \\
\hline
\end{tabular}

Soil reaction is controlled by the electrochemical properties of soil colloids. This term indicates the acidity and alkalinity of soil, the rank is determined by the concentration of hydrogen ions in the soil solution. Soil reaction ( $\mathrm{pH}$ value) can affect the supply of nutrients to the plant. The soil $\mathrm{pH}$ at the Gelam habitat was generally very acidic reaction, with $\mathrm{pH}$ values ranging from 3.46 to 3.86 . The low $\mathrm{pH}$ indicates the presence of pyrite layers of paint or clay. The $\mathrm{pH} 3.46-$ 3.86 included potential acidic-sulfate according Taxonomic-Soil. The study area contains of pyrite ranged from 0.42 to $2.20 \%$. The potential land is swamp land that has the potential acid sulphate soil types with pyrite content of $<2 \%$ with recesses $>50 \mathrm{~cm}$ from the ground (Noor 2004).

Organic carbons in swampy areas of gelam are generally high for the area having a high pile of material organic but on alluvial soil, organic carbon can be low. Result of laboratory analysis was the organic-C levels of 5.51 to $8.14 \%$ in Batola District and about $10,20 \%$ in Tapin District, with status of $\mathrm{C} \%$ had very low to moderate dignity.

Nitrogen is the nutrient that most often are in a state of deficiency for the plant, and is the fourth macro nutrients are important after carbon, hydrogen and oxygen. The nitrogen content in the region Barito Kuala ranged from 0.90 to $1.23 \%$, in Batola and about $1.29 \%$ in Tapin with dignity nutrient of nitrogen from very low to low.

\section{Conservation of Gelam}

For the conservation of gleams, the diameter $<4 \mathrm{~cm}$ should not be cut because these were too young and diameter $>30 \mathrm{~cm}$ not cut down and used as source of seeds, but in reality is still being done by the logging community. Generally, aged 3-5 years stand of Gelam can be harvested, so that rotation can be shortly.

Gelams in South Kalimantan Province are normally formed by small to large stem diameters of $3-5 \mathrm{~cm}, 10-$ $20 \mathrm{~cm}$ and $>20 \mathrm{~cm}$, this condition threatens the sustainability of Gelam. Under existing regulation in the Batola District that stem diameters of $<4 \mathrm{~cm}$ and $>30 \mathrm{~cm}$ should not be harvested for preservation purposes as mentioned before. This means that the regulations enacted there is not going well, so monitoring and strict enforcement needs to be done (Arifin et al. 2014).

In Hulu Sungai Selatan with partly a swamp forest and produce Gelam by Decree No. Hulu Sungai Selatan 
500/04 / Ekobang January 5, 2009 clearly states that the moratorium / termination / temporary ban logging in the forests of both people and other forest areas (Anonimous 2009). This situation shows that the gelam harvested in the district of Hulu Sungai Selatan is illegal. However, in reality the field is still outstanding gelam obtained from this region (Arifin et al. 2014). Gelam logging originating from South Kalimantan region is only used for local needs in the province. Shortage of supply of gelam for South Kalimantan region mostly from Kapuas Region.

\section{CONCLUSION}

Conclusions from the study can be summarized as follows:

1. Potential volume of Gelam in South Kalimantan Province is relatively small between $2.9-7.1 \mathrm{~m}^{3} / \mathrm{ha}$, originated from Central Kalimantan Province especially Kapuas District.

2. The soil $\mathrm{pH}$ of Gelam habitat is very acidic reaction ranging from 3.46 to 3.86 . The low $\mathrm{pH}$ indicates the presence of pyrite layers of paint or clay.

3. Management of Gelam in South Kalimantan in general is not in accordance with the regulations that threaten its sustainability.

\section{REFRENCES}

Anonimous, 2009. SK Bupati Hulu Sungai Selatan No. 500/04/Ekobang tanggal 5 Januari 2009.

Arifin Y F, Hamidah S, Arifin YF. 2014. The Analysis of Management and Timber Tread System of Galam (Melaleucacajuputi) from Peat Swamp Forest in South Kalimantan. Journal of Wetlands Environmental Management Vol 2, No. 2, August 2014, ISSN 2354-5844.

Dephut. 2003. Budidaya kayu Putih (Melaleuca cajuputi) (silviculture of kayu putih). Departemen Kehutanan, Jakarta. 29p.

Lazuardi D, Supriadi R. 2000. Teknik Pengelolaan Hutan Gelam Rakyat di Kalimantan Selatan (management technique of gelam forest in South Kalimantan). Laporan Hasil Penelitian (report of research). Balai Teknologi Reboisasi. Departemen Kehutanan. Badan Penelitian dan Pengembangan Kehutanan dan Perkebunan Banjarbaru.unpublished.

Mac Kinnon K, Hatta G, Halim H, Mangalik A. 1996. The ecology of Kalimantan (Indonesia Borneo). Periplus Editions (HK) Ltd. P130-458.

Noor M. 2004. Lahan Rawa, Sifat dan Pengelolaan Tanah Bermasalah Sulfat Masam. PT. Raja Grafindo Persada, Jakarta.

Samingan T. 1971. Tipe-tipe Vegetasi (Pengantar Dendrologi) Proyek Peningkatan /Pengem-bangan Perguruan Tinggi IPB, Bogor. 